
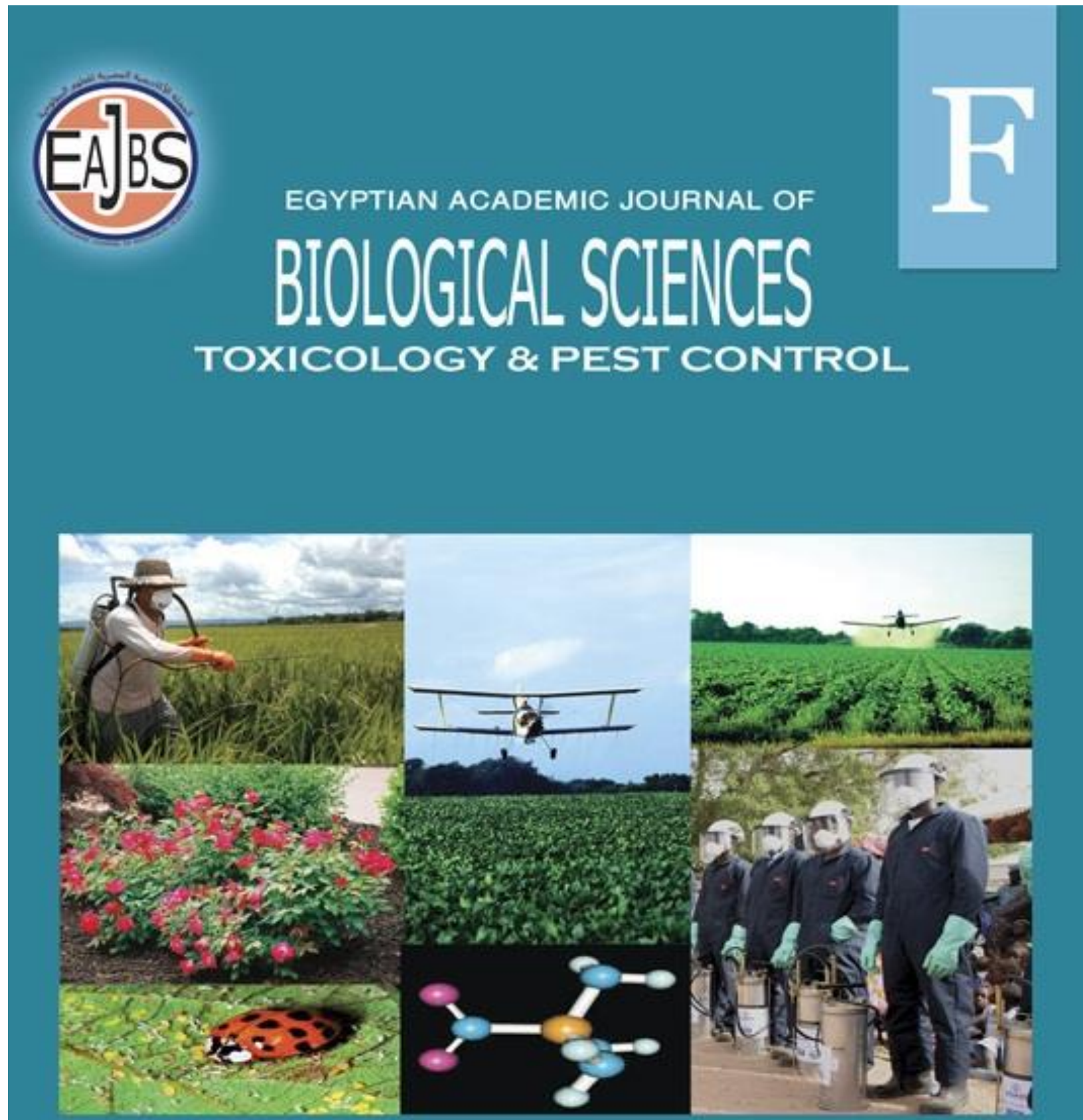

ISSN
$2090-0791$

WWW.EAJBS.EG.NET

Vol. 13 No. 2 (2021)

Citation: Egypt. Acad. J. Biolog. Sci. (F.Toxicology\& Pest control) Vol.13(2)pp173-182(2021) DOI: 10.21608/EAJBSF.2021.205956 
Egypt. Acad. J. Biolog. Sci., 13(2):173-182(2021)

Egyptian Academic Journal of Biological Sciences
F. Toxicology \& Pest Control
ISSN: 2090 - 0791
http://eajbsf.journals.ekb.eg/

\title{
Toxic Effect of Rosary Pea, Abrus precatorius L. Seeds Powder on Sitophilus granarius and Rattus rattus
}

\author{
Moamen A. Elbath* and Sara.E. El-Deeb \\ Plant Protection Department, Faculty of Agriculture, Benha University, Egypt \\ E-mail* moemen.elbath@ fagr.bu.edu.eg
}

\section{ARTICLEINFO}

Article History

Received:7/9/2021

Accepted:15/11/2021

\section{Keywords:}

Abrus

precatorius,

Sitophilus

granarius, Rattus

rattus, Toxicity,

Biochemical

parameters and

histopathology

\section{ABSTRACT}

The toxic effect of Abrus precatorius seeds powder against the wheat weevil Sitophilus granarius adults over a period of 14 days was studied. Data confirmed that, at all concentrations, the mortality percentage increased as the exposure period was prolonged and also as the applied concentration was increased. Seven days post-treatment the $\mathrm{LC}_{50}$ value was $0.12 \%(\mathrm{w} / \mathrm{w})$. The correspondent value at 14 days was significantly decreased being $0.05 \%(\mathrm{w} / \mathrm{w})$. Hence, A. precatorius seeds powder was toxic against $S$. granarius. The powder proved, also, that it had a repellent effect against the tested insect. The phytochemical investigation of $A$. precatorius seeds illustrated that it was rich in tannins, saponins and phenols. The $\mathrm{LC}_{50}$ and two higher concentrations of A. precatorius powder seeds were evaluated, also, against thirty-six adult males of Rattus rattus over a period of 30 days. Rats were randomly assigned to 4 groups 9 rats/ group. Rats of the first group were fed on grains mixed with $\mathrm{LC}_{50}(0.12 \%)$ of powder. The second group fed on grains mixed with 5\% powder. The third group was on grains mixed with $10 \%$ powder. While the fourth group was fed on untreated grains as control. Three replicates were used in each group. Blood samples were obtained for haematological and biochemical analysis. Specimens of the liver, kidney, spleen, testis, and stomach were, also, taken for histopathological studies. The whole results showed that the powder of $A$. precatorius seeds has potential toxicity as shown by the effects it caused on the serum chemistry as well as on the changes noted on the studied organs.

\section{INTRODUCTION}

Stored grain insects and rats are the leading factors causing damage and losses of stored products (Keskin and Özkaya 2013). The amount of damages caused by insects and rats in stored cereals and legumes is around 10-40\% in countries wherever modern storage techniques don't seem to be applied (Shaaya et al., 1997).

Problems of using pesticides are mainly environmental contamination, pests' resistance, and harmful to non-target organisms. Almost all types of pesticides are not selective, being broad spectrum and have adverse effects due to their toxicity (Ambethgar, 2009). One of the adverse effects of insecticides is killing the non-target organisms which also feed on the pests. These environmental and health concerns highlight the need for new strategies to protect stored products from pest infestation. 
One of the most damaging grain pest species is the grain weevil (Sitophilus granarius L.) (Boniecki et al., 2014). It can cause up to 5\% of losses in stored crops. This pest is commonly a cleverly hidden grain destroyer. Although the adult weevils can be easily detected during sieving, unfortunately, the identification of eggs, larvae, and pupae is difficult and requires appropriate laboratory tests. Weevils feeding on grains, significantly, reduce the germination capacity of grains from $93 \%$ to $7 \%$. Its presence and development cause an increase in humidity and temperature of the keep mass. These conditions make the development of fungi faster, as a result of the growth of grain mold, which in turn causes a drastic decrease in grain quality and consequently its value.

Rodents cause damage to stored food through direct damage, wastage, and contamination (Drummond, 2001) causing a decrease in both grain quantity and quality. Those, adversely, affect rural communities by damaging agricultural crops in the field by feeding and contaminating stored grains. Rats eat about $10 \%$ of their weight every day (Sayaboc et al., 1984) and contaminate much food with urine, hairs and faeces, thereby rendering it unfit for human consumption because the individual rat drops 25 to 50 pellets and voids 15 to $25 \mathrm{ml}$ of urine every day and constantly sheds some of each coat about 500.000 hairs (Howard and Marsh, 1976).

Abrus precatorius L. is a creeper plant with many branches (Gogte 2016). It belongs to the family Fabaceae. Nadkarni et al., 1942 found all throughout the plains from Himalayan down to Southern India and Ceylon. Flowers are pink, bluish and seem in clusters. Legumes are $1.5-3.5 \mathrm{~cm}$ long containing red, white and black coloured seeds. Red-colored seeds have black spots on their tips (Gogte 2016).

The present study seeks to establish the possible toxic effects of $A$. precatorius seeds powder on Sitophilus granarius adults, and by using serum biochemistry and histopathology as indices of toxicities in the rat.

\section{MATERIALS AND METHODS}

This work was carried out in the stored products laboratory, Plant Protection Department, Faculty of Agriculture at Moshtohor, Benha University.

\section{Plant and Preparation:}

Seeds of Abrus precatorius were purchased from Attarah store and dried seeds were ground to powder by using a hand grinder.

\section{Insects:}

A laboratory strain of the wheat weevil Sitophilus granarius L. used in these studies was obtained from the stored products laboratory, Plant Protection Dept. Fac. of Agriculture, Benha University and reared on wheat in a climate chamber at $28 \pm 1^{\circ} \mathrm{C}$ and $65 \pm 5 \%$ R.H. for about one year.

\section{Preparation of the Test-Insects for Various Treatments:}

A random replicate of $30 \mathrm{~S}$. granarius adults (7-14 days after emergence) was used in all experiments. Three replicates were used for every treatment.

\section{Laboratory Conditions:}

The experiments were conducted in the laboratory at $30 \pm 1^{\circ} \mathrm{C}$. and $65 \pm 5 \%$ R.H. to evaluate the efficiency of $A$. precatorius seeds powder.

The concentrations of $A$. precatorius seeds powder (w/w) used in this investigation were $0.5,0.25,0.125,0.0625$ and $0.03125 \%$.

\section{Repellent Activity Assay:}

Repellency experiment was carried out using an apparatus as described by $\mathrm{Su}$, (1989) with some modifications. The repellent activity was determined according to the following formula:

$$
\mathrm{PR}=(\mathrm{Nc}-\mathrm{NtNc}+\mathrm{Nt}) \times 100
$$


Where PR $=$ Repellent activity Percent, $\mathrm{Nc}=$ number of insects in control, $\mathrm{Nt}=$ number of insects in treatment. After calculating the average repellency values, these were rated in 0 5 scale as devised by Juliana and Su (1983). According to the scale $0 \leq 0.1 \%$ PR, $1=0.1-$ $20 \%$ PR, $2=>20.1-40 \%$ PR, $3=>40.1-60 \%$ PR, $4=>60.1-80 \%$ and $5=>80.1-100 \%$ PR.

\section{Qualitative Phytochemical Screening:}

Qualitative phytochemical analyses of seeds powder were conducted following the standard procedures of Harborne (1998).

Rats:

Thirty-six adult males of Rattus rattus were randomly collected from nearby villages and acclimatized to laboratory conditions for 2 weeks prior to the experimental study. The rat weighs approximately $150 \mathrm{gm}$.

\section{Experimental Design:}

Rats were randomly assigned to 4 groups, each of 9 rats: the first group was fed on grains mixed with $\mathrm{LC}_{50}(0.12 \%)$ of powder; the second group was fed on grains mixed with powder 5\%; the third group was fed on grains mixed with powder $10 \%$; the fourth group was fed on untreated grains as control. All rats of the various groups were fed wheat seeds for 30 days. Three replicates were carried out for every treatment.

\section{Biochemical Parameters:}

Blood samples were drawn on serum tubes. The serum levels of aspartate aminotransferase (AST), alanine aminotransferase (ALT) and alkaline phosphatase (ALP) were determined on a photoelectric colorimeter (Gallenkamp and Sons Ltd; England) as described by Toro and Ackermann (1975). Serum urea and creatinine levels were also determined on a photoelectric colorimeter (Gallenkamp and Sons Ltd, England) as described by Toro and Ackermann (1975).

\section{Histological Studies:}

Specimens from vital organs (liver, kidney, spleen, testis, and stomach) of treated male rats were collected after 30 days of treatment. Specimens from these organs were taken at the same interval from control rats for comparison. All specimens, except that of the testis, were fixed in 10\% neutral buffered formalin (Disbrey and Rack 1970) but those from testes were fixed in Bouin's fluid. The fixed specimens were dehydrated in ascending concentrations of ethyl alcohol, cleared in xylene, then immersed in paraffin wax. Paraffin blocks were cut in sections of 5 microns thickness. Sections were stained with hematoxylin and eosin for general structure (Harris 1989), periodic acid Schiff method for glycogen detection, and Masson's trichrome for identification of collagen fibers. Stained sections were examined for circulatory disturbances, inflammation, degenerations, apoptosis, necrosis and any other pathological changes in the examined tissues.

Statistical Analysis:

Mortality percentages were corrected according to Abbott's formula (1925). The obtained mortality data were subjected to Probit analysis (Finney 1971), using a computer program of (Noack and Reichmuth 1978).

The statistical analysis was carried out using one-way ANOVA using SPSS, ver. twenty-two (IBM Corp. Released 2013). Data were treated as a complete randomization design according to Steel et al. (1997). Multiple comparisons were carried out applying Duncun test and the significance level was set at $<0.05$.

\section{RESULTS}

Toxicity and Lethal Concentration (LC50) by Abrus precatorius Seeds Powder against of Sitophilus granarius Adults at $30 \pm 1^{\circ} \mathrm{C}$ and $65 \pm 5 \%$ R. H.:

Concentrations mortality data among S. granarius adults at $30 \pm 1{ }^{\circ} \mathrm{C}$ and $65 \pm 5 \%$ 
RH. After treatments by A. precatorius seeds powder are presented in Table (1). The obtained data indicated that mortality percentage increased by increasing the applied concentration and prolongation of the exposure period. The efficacies of A. precatorius seeds powder on mortality of $S$. granarius adults at $0.5,0.25,0.125,0.0625$ and $0.03125 \%$ concentrations were $11.67,8.33,5,0.0$ and $0.0 \%$, respectively, after one day exposure. All treated S. granarius adults died (100\%) after 5 days at the highest concentration of $0.5 \%$, and after 14 days post-treatment at $0.25 \%$. By treatment at lower concentrations $(0.125$, 0.0625 and $0.03125 \%$ ), mortality percentages reached $76.67,51.67$ and $41.67 \%$, respectively, 14 days post-treatment.

Table 1: Effect of feeding on wheat seeds treated by A. precatorius seeds powder on adult mortality of $S$. granaries.

\begin{tabular}{|c|c|c|c|c|c|c|c|}
\hline \multirow{2}{*}{$\begin{array}{c}\text { Concentrations } \\
\mathbf{\%}(\mathbf{w} / \mathbf{w})\end{array}$} & \multicolumn{6}{|c|}{ Accumulative Adult mortality (\%) after indicated days } \\
\cline { 2 - 8 } & $\mathbf{1}$ & $\mathbf{2}$ & $\mathbf{3}$ & $\mathbf{5}$ & 7 & $\mathbf{1 0}$ & $\mathbf{1 4}$ \\
\hline $\mathbf{0 . 5}$ & 11.67 & 33.33 & 71.67 & 100 & 100 & 100 & 100 \\
\hline $\mathbf{0 . 2 5}$ & 8.33 & 23.33 & 43.33 & 65 & 76.67 & 85 & 100 \\
\hline $\mathbf{0 . 1 2 5}$ & 5 & 8.33 & 10 & 28.33 & 40 & 46.67 & 76.67 \\
\hline $\mathbf{0 . 0 6 2 5}$ & 0.00 & 1.67 & 1.67 & 11.67 & 23.33 & 35 & 51.67 \\
\hline $\mathbf{0 . 0 3 1 2 5}$ & 0.00 & 0.00 & 0.00 & 1.67 & 8.33 & 20 & 41.67 \\
\hline
\end{tabular}

The lethal concentrations of A. precatorius seeds powder to adults of $S$. granarius are shown in Table (2). The results showed that after 7 days post-treatments, the $\mathrm{LC}_{50}$ value was $0.12 \%(\mathrm{w} / \mathrm{w})$. The corresponding value at 14 days post-treatment was significantly lower being $0.05 \%$ (w/w).

The findings of this investigation receive support from the previous researchers' achievements. Where it was found that $A$. precatorius seeds powder has the potential to be a good insecticide against some stored product insects. Results agree with the findings of Prasad et al. (2015), Bhattacharjee et al. (2019) and Chhabi et al. (2019).

Table 2: Toxicity values of $A$. precatorius seeds powder against at 7-, 10- and 14-days post-treatment adults of $S$. granarius at $30 \pm 1^{\circ} \mathrm{C}$ and $65 \pm 5 \%$ R.H.

\begin{tabular}{|c|c|c|c|c|c|}
\hline \multirow{2}{*}{$\begin{array}{c}\text { After } \\
\text { exposure } \\
\text { period } \\
\text { (Days). }\end{array}$} & \multicolumn{3}{|c|}{$\begin{array}{l}\text { Lethal concentrations }(\% w / w) \text { and their } 95 \% \\
\text { confidence limits. }\end{array}$} & \multirow{2}{*}{ Slope \pm SD } & \multirow{2}{*}{$\mathbf{R}$} \\
\hline & $\mathrm{LC}_{50}$ & $\mathrm{LC}_{90}$ & $\mathrm{LC}_{95}$ & & \\
\hline 7 & $\begin{array}{c}0.12 \\
(0.08-0.18) \\
\end{array}$ & $\begin{array}{c}0.37 \\
(0.24-0.56) \\
\end{array}$ & $\begin{array}{c}0.51 \\
(0.34-0.76) \\
\end{array}$ & $2.64 \pm 0.44$ & 0.97 \\
\hline 10 & $\begin{array}{c}0.09 \\
(0.06-0.14)\end{array}$ & $\begin{array}{c}0.32 \\
(0.20-0.51)\end{array}$ & $\begin{array}{c}0.46 \\
(0.29-0.73)\end{array}$ & $2.32 \pm 0.51$ & 0.95 \\
\hline 14 & $\begin{array}{c}0.05 \\
(0.03-0.09)\end{array}$ & $\begin{array}{c}0.20 \\
(0.11-0.35)\end{array}$ & $\begin{array}{c}0.29 \\
(0.16-0.52)\end{array}$ & $2.09 \pm 0.64$ & 0.96 \\
\hline
\end{tabular}

\section{Repellent Activity of $A$. precatorius Seeds Powder against $S$. granarius:}

Powder of $A$. precatorius seeds showed varying repellent activity for $S$. granarius depending on time and the used concentration (Table 3). Repellency was measured after $1,2,4$, and 8 hours of treatment. Results showed that repellency increased with increasing concentration and reduced with increasing the period of exposure. The powder of $A$. precatorius seeds achieved $81.81 \%$ repellency after an hour at the concentration $(0.5 \%)$. The low concentration $(0.0625 \%)$ manifested the lowest repellent activity against $S$. 
granarius adults ( $16.67 \%$ repellency) was recorded, while, at $0.03125 \%$ concentration, no repellent effect was observed on $S$. granarius adults. These observations are confirmed by the findings of Chhabi et al. (2019) who reported that the extracts of seeds and roots of $A$. precatorius caused moderate repellent activity at a $1 \%$ level of significance against $T$. castaneum adults.

Table 3: Repellent activity of $A$. precatorius seeds powder against $S$. granarius adults at $30 \pm 1^{\circ} \mathrm{C}$ and $65 \pm 5 \%$ R.H.

\begin{tabular}{|c|c|c|c|c|c|}
\hline \multirow{2}{*}{$\begin{array}{c}\text { Concentrations } \\
\%(w / w)\end{array}$} & \multicolumn{4}{|c|}{ Exposure period (hours) } & \multirow{2}{*}{$\begin{array}{l}\text { Mean repellent } \\
\text { activity (scale } \\
\text { value) }\end{array}$} \\
\hline & $1 \mathrm{~h}$ & $2 \mathrm{~h}$ & $4 h$ & $8 \mathbf{h}$ & \\
\hline 0.5 & 81.81 & 77.77 & 75 & 71.42 & $76.5(\mathrm{~V})$ \\
\hline 0.25 & 75 & 66.66 & 60 & 50 & 62.92 (IV) \\
\hline 0.125 & 60 & 60 & 50 & 33.33 & 50.83 (III) \\
\hline 0.0625 & 33.33 & 33.33 & 0.00 & 0.00 & $16.67(\mathrm{I})$ \\
\hline 0.03125 & 0.00 & 0.00 & 0.00 & 0.00 & 0.00 \\
\hline
\end{tabular}

\section{Qualitative Phytochemical Screening:}

The insecticidal activities of $A$. precatorius seeds powder which were tested for the insecticidal activities on the adult of $S$. granarius were screened phytochemically. Airdried powder of $A$. precatorius was phytochemically screened for its constituents of glycosides, tannins, flavonoids, saponins, steroids, alkaloids, phenols and terpenoids. Obtained data is shown in Table (4).

Table 4: Preliminary phytochemical screening of dried powder of A. precatorius seeds:

\begin{tabular}{|l|c|c|c|c|c|c|c|c|}
\hline $\begin{array}{c}\text { Tested } \\
\text { phytochemicals }\end{array}$ & Glycosides & Tannins & Flavonoides & Saponins & Steroids & Alkaloids & Phenols & Terpenoids \\
\hline A. precatorius & + & +++ & + & +++ & + & + & +++ & + \\
\hline
\end{tabular}

$(+++)$ high amount, $(++)$ moderate amount, $(+)$ low amount

Results illustrated that $A$. precatorius seeds are rich in tannins, saponins and phenols. These results agree with those obtained by Ogbuehi et al. (2015), Sunday et al. (2016), Boggula et al. (2017) and Saraf et al. (2018).

\section{Biochemical Parameters:}

Data presented in Table (5) demonstrate the extent effects of $A$. precatorius seeds powder at $0.12,5$ and $10 \%$ concentrations on the liver and kidney functions by measuring some biochemical changes in $R$. rattus blood. Concentrations $0.12,5$ and $10 \%$ increased ALT from 20.1 (U/L) in blood of control rats to 20.2, 25.8 and 30.7 (U/L), respectively. At the same concentrations, the tested concentrations increased AST from 180.5 (U/L) (control) to 220.6, 240.2 and 295.7 (U/L), respectively. Similarly, the ALP activities increased from 85.6 (U/L) (control) to 85.9, 87.6 and 90 (U/L), respectively. At the same powder concentrations, urea increased in the blood of rats from 41.71 (control) to 43.6, 47.6 and 49.6 respectively. On contrary, the creatinine declined from 0.35 (control) to $0.31,0.20$ and 0.15() , respectively.

Thus, it becomes clear that powder of $A$. precatorius seeds led to the occurrence effects on the liver and kidney functions. These results are in the same line as those of Adedapo et al. (2007) and Madaki et al. (2019). 
Table 5: Effect of A. precatorius seeds powder on ALT, AST, ALP, urea and creatinine in blood of rats:

\begin{tabular}{|c|c|c|c|c|c|}
\hline Treatment & ALT (U/L) & AST (U/L) & ALP (U/L) & Urea & Creatinine \\
\hline control & $20.1^{\mathrm{c}}$ & $180.5^{\mathrm{d}}$ & $85.6^{\mathrm{d}}$ & $41.7^{\mathrm{d}}$ & $0.35^{\mathrm{a}}$ \\
\hline A. precatorius $(\mathbf{0 . 1 2 \% )}$ & $20.2^{\mathrm{c}}$ & $220.6^{\mathrm{c}}$ & $85.9^{\mathrm{c}}$ & $43.6^{\mathrm{c}}$ & $0.31^{\mathrm{b}}$ \\
\hline A. precatorius $\mathbf{5 \%} \%$ & $25.8^{\mathrm{b}}$ & $240.2^{\mathrm{b}}$ & $87.6^{\mathrm{b}}$ & $47.6^{\mathrm{b}}$ & $0.20^{\mathrm{c}}$ \\
\hline A. precatorius $\mathbf{( 1 0 \% )}$ & $30.7^{\mathrm{a}}$ & $295.7^{\mathrm{a}}$ & $90^{\mathrm{a}}$ & $49.6^{\mathrm{a}}$ & $0.15^{\mathrm{d}}$ \\
\hline
\end{tabular}

Means in the same column with different superscript letters are significantly different at $P<0.05$

\section{Histological Studies:}

Results of the histological effect of A. precatorius seeds powder on Rattus rattus organs (liver, kidney, spleen, testis, and stomach) are shown in Figs. (1- 4).

\section{Histological Studies of Rat Organs Before the Treatment:}

The histology sections of the liver in the control treatment revealed normal hexagonal plates of hepatocytes. The Liver acinus which is the functional unit is ovalshaped. Its short arm is represented by a shared border between two adjacent lobules together with the portal canals. (Figs.1 A\&B). Examined sections from the kidney pointed out cortical and medullary structures in continuity. The functional unit is the nephron; it consists of the glomerulus, open in the proximal and distal tubule, in the descending and ascending Henle loop and in the straight portions. (Figs.1 C\&D). Examined sections from the spleen demonstrated a red pulp composed of splenic cords and venous sinuses. The splenic cords are formed from reticulin fibers, reticular cells, and associated macrophages (monocytes) (Figs. $1 \mathrm{E} \& \mathrm{~F}$ ). The intestine is subdivided into (small) and (large) ones. Through the entire length of the intestine, there are three layers (mucosa with submucosa, muscular and serous). The mucosa has lining epithelium and fibrovascular stroma called "own blade" which is separated from the submucosa by "mucosal muscular lamina" (a thin layer of smooth muscle) (Figs.1 G\&H). Examined sections from testes showed normal testicular structures with preserved seminephrous tubules which appeared lined by normal spermatogonia, spermatocytes, spermatids and sertoli cells; they contained a variable number of mature spermatozoa in their lumina. ledying cells, intesrstitial tissue and vascular structures were apparently normal (Figs.1 I\&J).

\section{Histological Studies of Rat Organs After Treatments:}

\subsection{Effect of $A$. precatorius Seeds Powder at $(0.12 \%)$ :}

Examined sections after treatment at $0.12 \%$ powder revealed histomorphologic changes represented by hepatic portal round cells aggregations, mild biliary proliferation and hepatocellular hydropic degeneration. Renal tubular degeneration, hyaline cast formation and tubular dilatation were seen. The spleen showed moderate depletion of the white pulp lymphoid cells. The small intestine showed villitis, villous stratification and an increase in the number of goblet cells. Focal testicular edema, atrophy, besides degenerative and necrotic changes in spermatogonia and spermatocytes of some seminiferous tubules were seen (Fig. 2).

\subsection{Effect of $\boldsymbol{A}$. precatorius Seeds Powder at (5\%):}

At $5 \%$ vascular dilatation portal round cell aggregations, mild biliary proliferation and hepatocellular degeneration, renal moderate hyperemia, moderately dilated collecting tubules, peritubular round cells aggregation and lobulated glomerular tufts, splenic moderate to marked lymphoid hypoplasia, intestinal villous stunting, increased number of goblet cells and mucosal round cells infiltration in addition to testicular congestion, edema, atrophied seminiferous tubules and focal degenerative and necrotic changes in the spermatogonia and spermatocytes with the partial arrest of spermatogenesis were recorded (Fig.3). 


\subsection{Effect of $A$. precatorius Seeds Powder at (10\%):}

At $10 \%$ Hepatic marked vascular dilation, portal biliary proliferation and round cells infiltration, besides hepatocellular hydropic degeneration were seen. Renal vascular dilation, perivascular edema, shrinkage in a moderate number of glomeruli and moderate tubular dilatation were recorded. Spleen with marked lymphoid hypoplasia, intestine with moderate villous stunting and increase in the number of goblet cells beside and testicular hyperemia, edema, seminiferous tubular atrophy, degenerative and necrotic changes in spermatogonia and spermatocytes with partial to complete arrest of spermatogenesis were seen (Fig.4).

A negative effect appeared on vital organs especially testis; partial arrest of spermatogenesis was a record by Jahan et al. (2009) and Ogbuehi et al. (2015).

This study showed that $A$. precatorius seeds powder has potentially toxic effects as shown by the effects caused on the serum chemistry as well as on the changes noted on the treated organs.

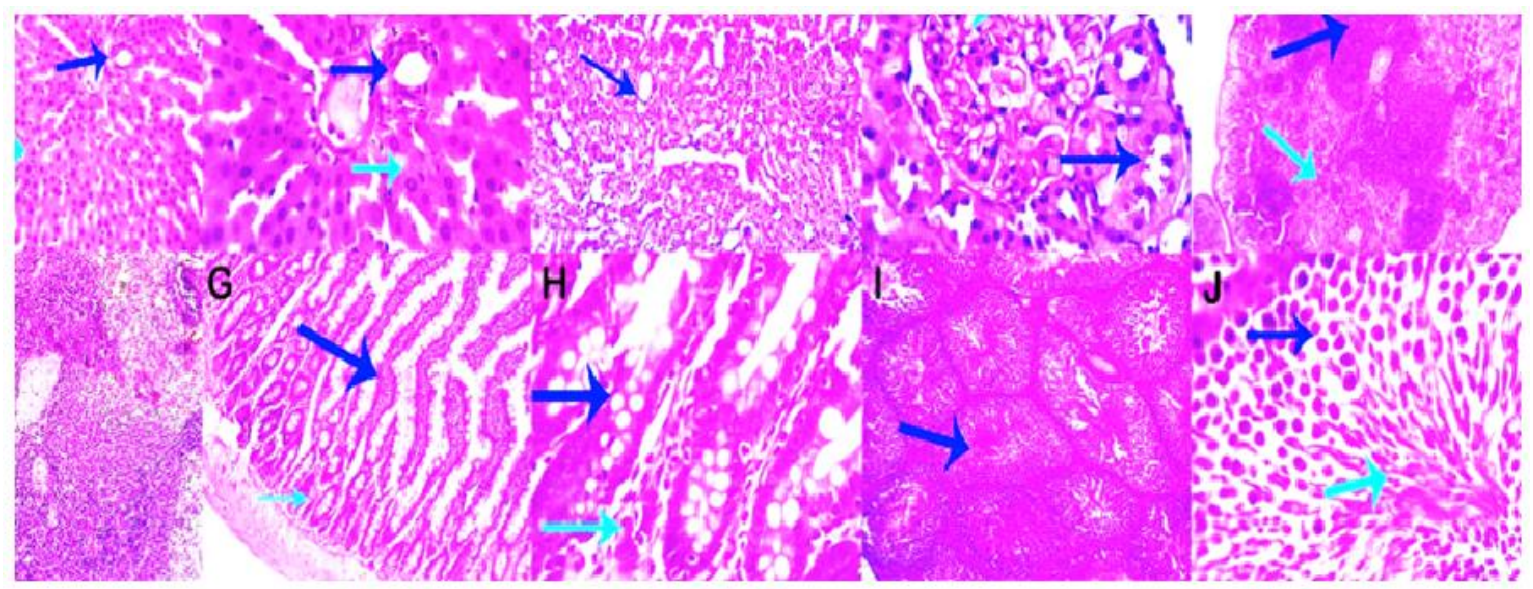

Fig.1: Photomicrograph from liver (A,B ), kidney (C,D ), spleen (E,F ), intestine (G,H) and testis ( I,J ) of control rats, showing normal histomorphology of the corresponding organs . The hepatic cords (light blue arrow), portal area (deep blue arrows), renal tubules (deep blue arrows), glomeruli (light blue arrows), splenic white pulp (deep blue arrows), red pulp (light blue arrows), intestinal villi (deep blue arrows , intestinal mucosa ( light blue arrows) and testicular seminiferous tubules(deep blue arrows) and spermatozoa (light blue arrows), all are seen with apparent normal arrangement and histological structures).H\&E X 100, 200,400 .

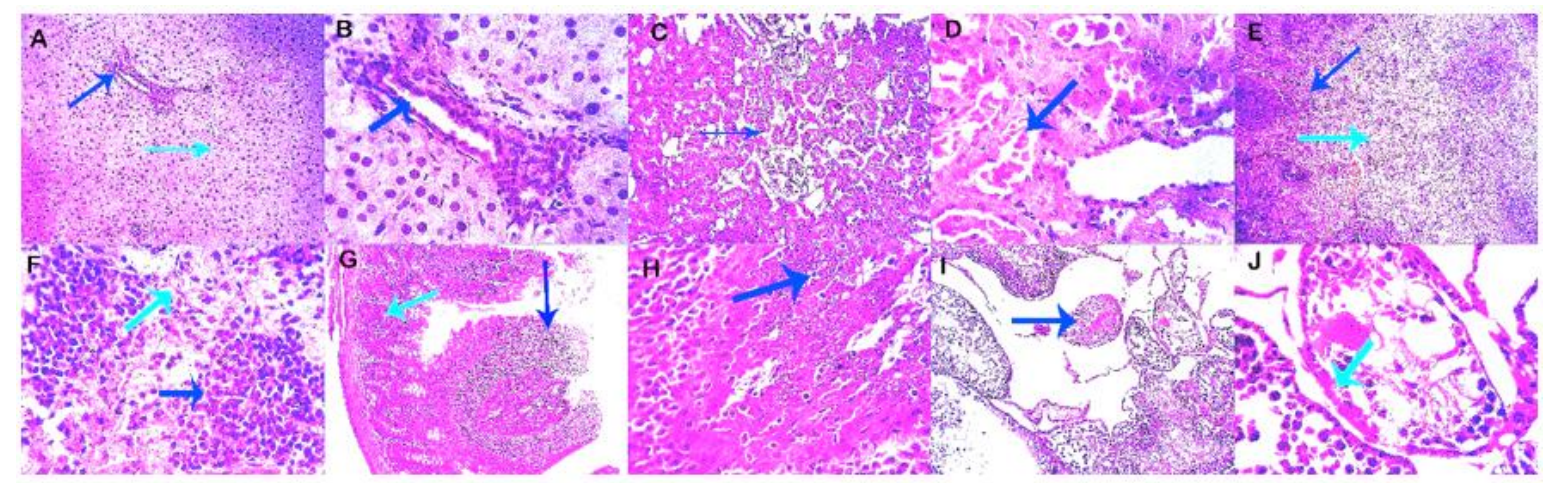

Fig.2: Photomicrograph from liver (A,B ), kidney (C,D ), spleen (E,F ), intestine ( G,H) and testis ( I,J ) of ( plant 1 ), showing at $0.12 \%$ hepatic portal round cells aggregations, mild biliary proliferation and hepatocellular hydropic degeneration(dark and light blue arrows ). Renal tubular degeneration, hyaline cast formation and tubular dilatation are seen (dark and light blue arrows). The spleen shows moderate depletion of the white pulp lymphoid cells (dark blue arrows). The small intestine shows villitis, villous stratification and increase in number of goblet cells. Focal testicular edema, atrophy, beside degenerative and necrotic changes in spermatogonia and spermatocytes of some seminiferous tubules are seen (dark and light blue arrows). H\&E X 100, 200. 


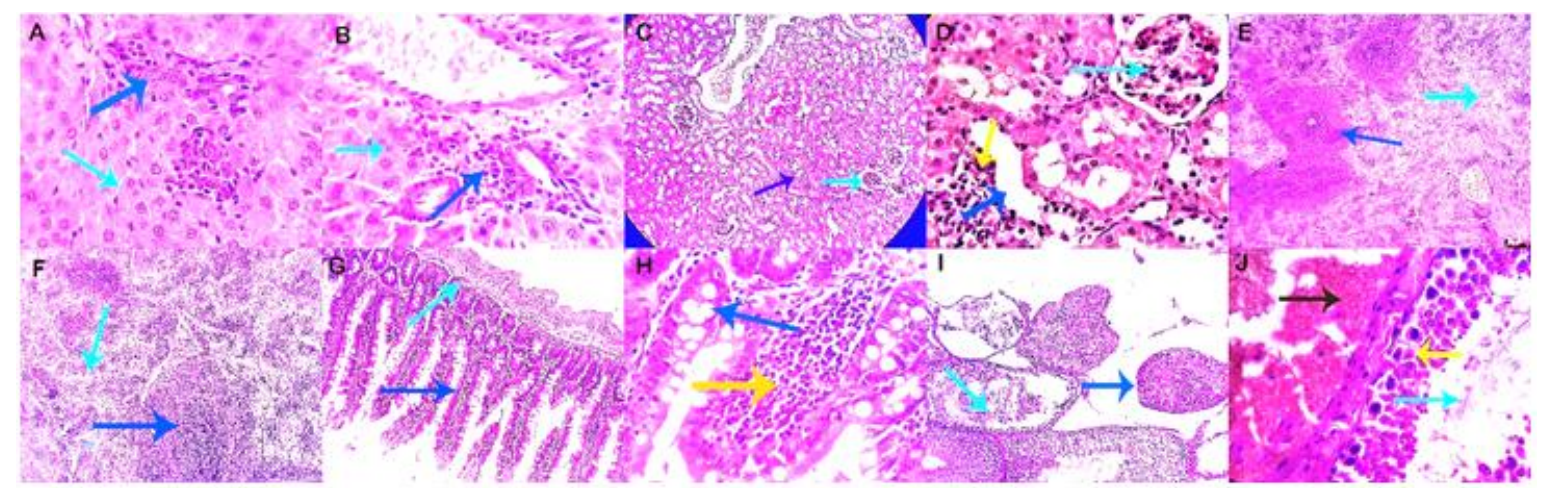

Fig.3: Photomicrograph from the liver $(A, B)$, kidney $(C, D)$, spleen $(E, F)$, intestine $(G, H)$ and testis ( I,J ) of (plant 1), showing at $5 \%$ vascular dilatation portal round cell aggregations, mild biliary proliferation and hepatocellular degeneration(dark and light blue arrows), renal moderate hyperemia, moderately dilated collecting tubules, peritubular round cells aggregation and lobulated glomerular tufts (dark blue arrow light blue arrow and yellow arrow), splenic moderate to marked lymphoid hypoplasia(dark blue arrows), intestinal villous stunting, increased number of goblet cells and mucosal round cells infiltration(dark blue arrow, light blue arrow and orange arrow) in addition to testicular congestion, edema, atrophied seminiferous tubules and focal degenerative and necrotic changes in the spermatogonia and spermatocytes with the partial arrest of spermatogenesis are seen(dark and light blue arrows). H\&E X 100, 200.

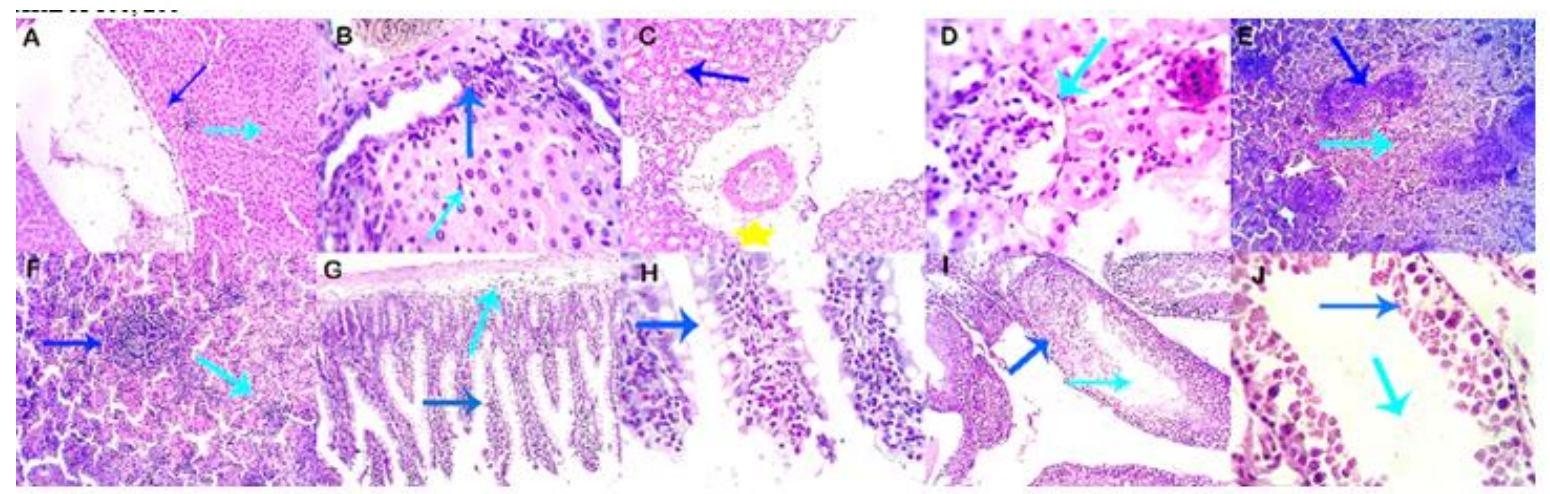

Fig.4: Photomicrograph from the liver (A,B), kidney $(\mathrm{C}, \mathrm{D})$, spleen $(\mathrm{E}, \mathrm{F})$, intestine $(\mathrm{G}, \mathrm{H})$ and testis ( I,J ) of (plant 1), showing at10\% Hepatic marked vascular dilation, portal biliary proliferation and round cells infiltration, beside hepatocellular hydropic degeneration are seen (dark and light blue arrows). Renal vascular dilation, perivascular edema, shrinkage in a moderate number of glomeruli and moderate tubular dilatation are seen (dark and light blue arrows and yellow star). Spleen with marked lymphoid hypoplasia(dark blue arrows), intestine with moderate villous stunting and increase in the number of goblet cells (dark and light blue arrows) beside testicular hyperemia, edema, seminiferous tubular atrophy, degenerative and necrotic changes in spermatogonia and spermatocyte with partial to complete arrest of spermatogenesis are seen (dark and light blue arrows). H\&E X 100, 200.

\section{Conclusion}

Results of the present study showed the toxic and repellent effects of Abrus precatorius plant on Sitophilus granarius and Rattus rattus. So it may be recommended to be used in the prevention and control of $S$. granarius and $R$. rattus without mixing with the stored products. Where it can be used in the operations of disinfecting warehouses, used on the ground next to the stored products and it is placed around the store from the outside, due to its toxicity to mammals.

\section{REFERENCES}

Abbott; W. S. (1925): A method of computing the effectiveness of insecticide. Journal of Economic Entomology, 18 (2), 265-267. 
Adedapo, A.A.; Omoloye, O.A. and Ohore, O.G. (2007) Studies on the toxicity of an aqueous extract of the leaves of Abrus precatorius in rats. Onderstepoort Journal of Veterinary Research; 74:31-36.

Ambethgar, V. (2009) Potential of entomopathogenic fungi in insecticide resistance management (IRM): A review. Journal of Biopesticides; 2(2):177-193.

Bhattacharjee, S. C.; Matin M. M. and Nasiruddin M. (2019). Insecticidal effects of two medicinal plants Polygonum hydropiper L. and Abrus precatorius L. leaves against the rice weevil Sitophilus oryzae L. (Coleoptera: Curculionidae). Journal of Biodiversity Conservation and Bioresource Management, 5(2) 107:114.

Boggula, N.; Swetha, R. N. R.;Teja, S. A.; Azmath, F.; Jainendra, B. and Vasudha, B. (2017): Phytochemical Evaluation and In-vitro Anti-Bacterial Activity of Dried Seeds of Abrus precatorius. International Journal of Pharmaceutical Sciences Review and Research, 44(1): 101-107.

Boniecki, P.; Piekarska-Boniecka, H.; 'Swierczy' nski, K.; Koszela, K.; Zaborowicz, M. and Przybył, J. (2014): Detection of the granary weevil based on X-ray images of damaged wheat kernels. The Journal of Stored Products Research, 56: 38-42.

Chhabi, S. B.; Shamima, S.; Shahriar, Z., Mohammad, A. and Nurul Islam (2019): Biological activity of Abrus precatorius L. through dose-mortality, repellent activity and Brine shrimp lethality tests. Journal of Entomology and Zoology Studies; 7(3): 13-16.

Drummond, D.C. (2001): Rodents and biodeterioration. International Biodeterioration and Biodegradation, 48, 105e111.

Finney; D. J. (1971): "Probit Analysis". Cambridge University Press, Cambridge, London, 333pp.

Gogte, V.V.M. (2016) Ayurvedic pharmacology and therapeutic uses of medicinal plants Dravyagunavignyan, Chaukhambha Publications, Mumbai, 2009; 841pp.

Harborne, J. B. (1998) Phytochemical methods; a guide to modern technique of plant analysis", 2nd ed., London: Chapman and Hall.;282.

Harris; H. F. (1989) Carletons Histological Techniques. $4^{\text {th }}$ Ed. Oxford Univ. Press, Ner York, Toronto.

Howard, W. and Marsh R.E. (1976). The rat: Its biology and control. Division of Agricultural Sciences Leaflet No. 2896. Cooperative Extension, University of California Division of Agriculture Sciences, leaflet no. 2896 pp.

Jahan, S.; Salma, R.;Mir, A. K.; Mushtaq, A.; Muhammad, Z.; Muhammad, A. and Arshad, M. A. (2009) Antifertility effects of ethanolic seed extract of Abrus precatorius L. on sperm production and DNA integrity in adult male mice. Journal of Medicinal Plants Research, 3(10), 809-814.

Juliana, G.; Su, H.C.F. (1983) Laboratory studies on several plant materials as insect repellents for protection of cereal grains. Journal of Economic Entomology, 76:154-157.

Keskin, Ş. Özkaya, H. (2013) Insect growth and its effects on cereals during storage. Academic Food Journal,11(3):101-105.

Madaki, F. M.; Adamu, Y. K.; Olofu, O. E. and Abdullahi, M. (2019): Antioxidant properties and effect of Abrus precatorius leaves extract on haematological and biochemical parameters in rats. Iranian Journal of Toxicology; 13 (2):13-18.

Nadkarni, K.M.; Indian, M. M. (1942) 3rd ed., Popular Book Depot, Mumbai 7; Dhootapapeswar Prakashan Ltd. Panvel, Mumbai, 966 pp.

Noack; S. and Reichmuth; C. H. (1978): Einrechnerisches Verfahren Zur Bestimmung Von beliebigen Dosis-Werten eines Wirkstoffes aus empirisch Dosis-wirkungs-Daten Mitt. Boil Bundesanstalt fur Land Forstwirtsch, Berlin Dahlem, Haft, 185:1-49. 
Ogbuehi, I. H.; Ebong, O. O. and Obianime, A. W. (2015) A Preliminary Study on the Effect of Abrus precatorius Linn. on Reproductive Parameters in Female Rattus norvegicus, Wistar Strain. European Journal of Medicinal Plants, 7(3): 156-166.

Prasad, R.; Gilianne, B.; Casper, V. and Simon, H. (2015) Potential of the weed Abrus precatorius Linnaeus (Fabales: Fabaceae) for control of insect pests in the south pacific: a review. International Journal of Entomology Research, 03 (03):113124.

Saraf, A.; Aparna, S. and Alka, C. (2018). Phytochemical Analysis and Chemical Fingerprinting of Seeds of Abrus Precatorius L. Chemical Science Transactions, 7(1): 63-70.

Sayaboc, P.D.; Caliboso F.M.; Benigno E.A. and Hilario J. (1984). Rodent losses in commercial grain storage. Presented at Grain Post Harvest Workshop. ASEAN Crops, Post-Harvest Program. August 1984. Kuala Lumpur.

Shaaya, E.; Kostjucovski, M.; Eilberk J. and Sukprakarn, C. (1997) Plant oils as fumigants and contact insecticides for the control of stored product insects. The Journal of Stored Products Research, 33:7-15.

Su, H. C.F. (1989): Laboratory evaluation of dill seed extract in reducing infestation of rice weevil in stored wheat. Journal of Entomological Science, 24:317-320.

Sunday, O. J.; Shola, K. B.; Adeyinka, E. A.; Racheal, M. A.; Mufutau, A. A. and Busayo, I. A. (2016) Evaluation of phytochemical properties and in-vitro antibacterial activity of the aqueous extracts of leaf, seed and root of Abrus precatorius Linn. against Salmonella and Shigella. Asian Pacific Journal of Tropical Biomedicine, 6(9): 755-759.

Steel, R.; Torrie, J. and Dickey, D. (1997): Principles and procedures of Statistics: A Biometrical Approach, $3^{\text {rd }}$ ed., McGraw-Hill, New York, NY.

Toro, G. and Ackermann, P. (1975): Practical clinical chemistry, $1^{\text {st }}$ ed. Boston: Little Brown \& Co.W.B. Saunders Company.

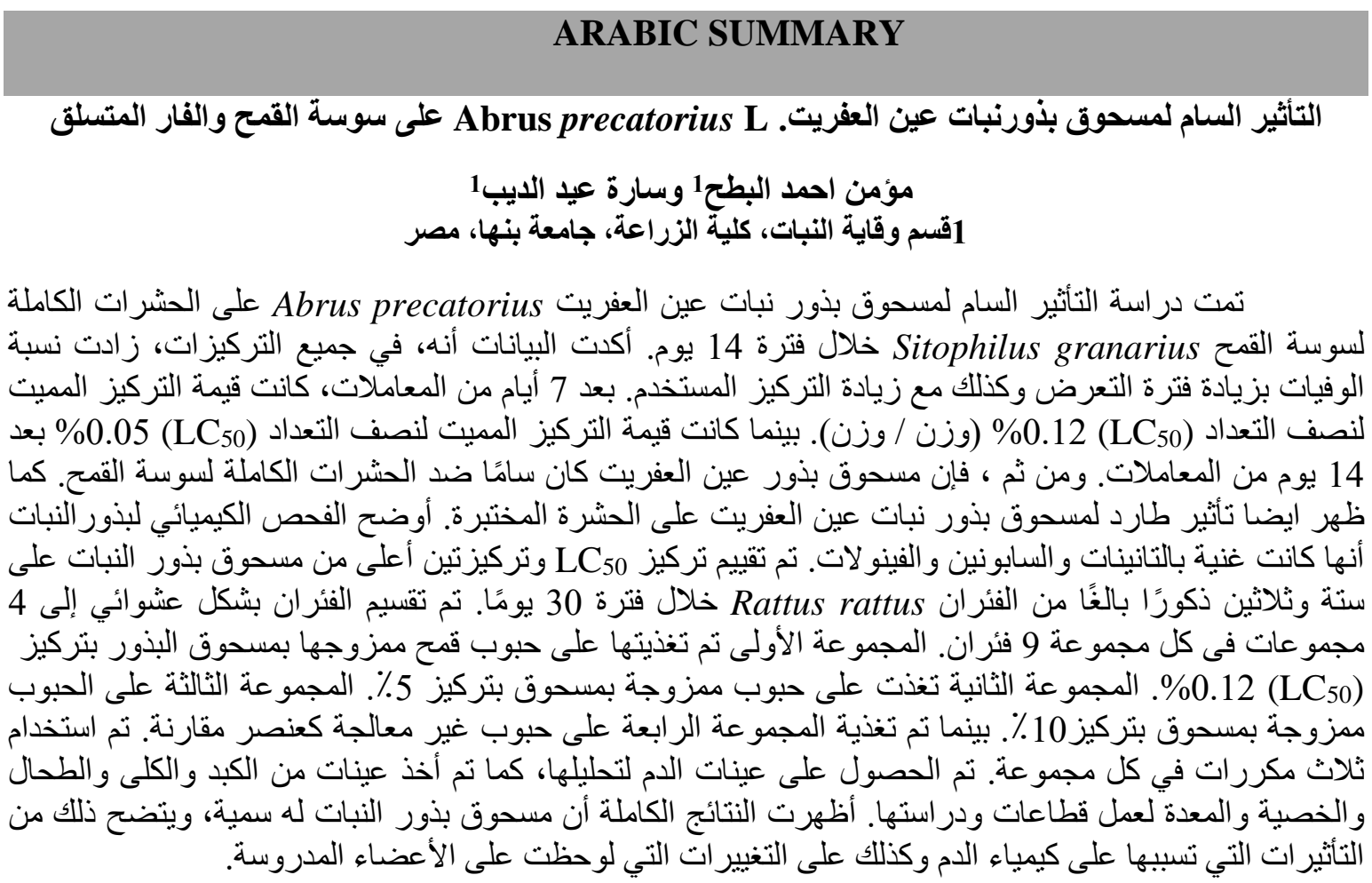

